\title{
POWOŁYWANIE SIĘ NA ZASADĘ SŁUSZNOŚCI JAKO ARGUMENT W DYSKURSIE PRAWNICZYM NA PRZYKŁADZIE ORZECZNICTWA SĄDU NAJWYŻSZEGO
}

\section{Wprowadzenie}

Nie budzi wątpliwości, że idealnym „,polem” dla zaprezentowania argumentów stosowanych w dyskursie prawniczym są uzasadnienia orzeczeń Sądu Najwyższego. Dochodzi tam do rozważenia powstałych w toku postępowania przed sądami pierwszej i drugiej instancji problemów prawnych. Wprawdzie nie każdy judykat, czy też zbiór judykatów (dotyczących określonego problemu prawnego) jest skarbnicą przykładów argumentacji w praktycznym dyskursie prawniczym, jednak wiele efektów pracy tego naczelnego organu władzy sądowniczej w Polsce jest wartych uwagi. W niniejszym artykule przeanalizuję, pod kątem użycia wyróżnionych przez literaturę argumentów, orzeczenia Sądu Najwyższego poruszające problem możliwości zastosowania przepisu art. 5 Kodeksu cywilnego (Dz.U. Nr 16, poz. 93 ze zm.) jako podstawy obniżenia spłat lub dopłat z udziałów przy podziale majątku wspólnego. Jednocześnie poruszę kwestię powoływania zasady słuszności jako rodzaju argumentacji w dyskursie prawniczym.

\section{Dyskurs prawniczy}

Analizę argumentów w dyskursie prawniczym warto poprzedzić wyjaśnieniem pojęcia samego „dyskursu”. J. Stelmach i B. Brożek wskazują, że stworzenie definicji dla tego pojęcia jest dużym wyzwaniem. Powątpiewają, czy w ogóle jest to możliwie. Podają jednak, że przy budowie definicji analitycznej (sprawozdawczej), odtwarzającej zastany (historycznie) sens, należałoby uwzględnić takie intuicje znaczeniowe, jak: proces poznania, komunikacji, dowodzenia logicznego, dysku- 
sji, przemawiania, przekonywania za pośrednictwem mowy itp. Dyskursem mogą zostać oznaczone zarówno ogólne procesy powiązane z poznaniem i komunikacją, jak i szczegółowe czynności związane z metodą prowadzenia dyskusji. Użycie jednak jednej intuicji znaczeniowej dla pojęcia dyskursu, z racji braku kryterium wyboru, jest nieuprawione. Przy czym skorzystanie z wielu intuicji znaczeniowych, dla skonstruowania przedmiotowej definicji, czyni ją bezużyteczną dla wyspecjalizowanych rodzajów rozważań. Z kolei definicja syntetyczna (projektująca) jest uznawana przez wyżej wskazanych za arbitralną, albowiem przymusza do wyboru tylko jednej intuicji znaczeniowej, odwołującej się do osobistego rozumienia dyskursu przez jej konstruktora. ${ }^{1}$

Wspomniany, trudny do właściwego zdefiniowana „dyskurs”, dzieli się między innymi na dyskurs teoretyczny, w którego toku następuje przyznanie waloru prawdziwości, bądź piętna fałszu wypowiedziom opisowym, oraz dyskurs praktyczny, nakierowany na stwierdzenie poprawności, trafności, czy też nietrafności wypowiedzi pozaopisowych, głównie norm. ${ }^{2}$ Ponadto rozróżnia się dyskurs ogólny i szczegółowy, którego przykładem mógłby być, zdaniem J. Stelmacha i B. Brożka, właśnie dyskurs prawniczy. ${ }^{3}$

Dyskurs prawniczy, który wedle koncepcji Alexego jest szczególnym przypadkiem ogólnego dyskursu praktycznego (fundamentem rozstrzygnięć judykatury są argumenty, które odwołują się do norm i ocen pozaprawnych; argumenty oparte jedynie na przepisach prawa, mogą stanowić podstawę rozstrzygnięć $\mathrm{w}$ sprawach prostych, gdzie nie istnieje potrzeba wyboru między wartościami), ${ }^{4}$ a zgodnie z koncepcją Perelmana ma paradygmatczyny charakter dla wszelkich innych typów rozumowań praktycznych. ${ }^{5}$ We współczesnej filozofii argumentacyjnej istotną rolę odegrały dwa ujęcia dyskursu prawniczego: topiczno-retoryczny oraz formalny. ${ }^{6}$ Pierwsze ze wskazanych ujęć sięga do technik prowadzenia dyskursu, takich jak topika i retoryka, drugie zaś polega na przedstawieniu procedury, według której argumentacja ma być prowadzona. ${ }^{7}$

Modelowym przykładem dyskursu prawniczego jest proces sądowy, w którym dyskurs ukierunkowany jest na osiągnięcie rozstrzygnięcia $\mathrm{w}$ zakresie zgodności określonych zachowań podmiotów prawa z normami prawa. Celem takiego dyskursu jest wydanie, w rozsądnym czasie, stanowczego i jednoznacznego rozstrzy-

Zob. J. Stelmach, B. Brożek, Metody Prawnicze, Logika, analiza, argumentacja, hermeneutyka, Kraków 2006, s. $178-179$.

Zob. J. Oniszczuk, Filozofia i teoria prawa, Warszawa 2008, s. 768.

J. Stelmach, B. Brożek, Metody..., op. cit., s. 178.

Zob. K. Kukuryk, Kilka uwag o sposobie rozstrzygania dyskursu prawniczego, „Anales Universitatis Marie Curie-Skłodowska Lublin-Polonia” 2012, Vol. LIX, 1, s. 23, http://annales.umcs.lublin.pl/tt_p.php?rok=2012\&tom=59\&sectio=G\&numer_artykulu=02\&zeszyt=1, 10.05.2014 r. Zob. J. Stelmach, B. Brożek, Metody..., op. cit., s. 162.

Ibidem, s. 192.

Zob. S. Lewandowski, Retoryczne i logiczne podstawy argumentacji prawniczej, Warszawa 2013, s. 117-120. 
Powoływanie się na zasadę słuszności jako argument w dyskursie prawniczym...

gnięcia. Istotny element takiego dyskursu stanowią przepisy prawa materialnego i proceduralnego, nakreślające granice sporu. ${ }^{8}$

J. Stelmach, B. Brożek wyróżnili trzy reguły rządzące dyskursem prawniczym:

- reguły ogólne, stanowiące jednocześnie procedurę, jak i etykę dyskursu $\mathrm{w}$ rozumieniu formalnym (dyskurs prawniczy winien być prowadzony z przekonaniem o jego słuszności, poszanowaniem prawdomówności, zasad wolności i równości oraz tylko dla przypadków trudnych; winien ponadto uwzględniać podstawowe zasady komunikacji językowej, ustalenia faktyczne, powszechnie akceptowane standardy praktyki i zwyczaje; winien również zmierzać bezpośrednio do celu);

- reguły przejścia, pozwalające zrozumieć istotę relacji istniejącej między ogólnym dyskursem praktycznym a dyskursem prawniczym (dyskurs prawniczy powinien uwzględniać reguły ogólne dyskursu prawniczego; winien być prowadzony w bezpośrednim związku z obowiązującym prawem; ograniczenia zakresu zastosowania reguł ogólnych w dyskursie prawniczym można dokonać jedynie w sytuacji, gdy wynika to bezpośrednio z przepisów obowiązującego prawa);

- topiki prawnicze, mające w przeciwieństwie do dwóch powyższych, przesądzających o proceduralnym charakterze, wyznaczających jego ramy reguł, charakter materialny (zasady prawne, np. zasada ogólna - pacta sunt servanda, zasada interpretacyjna - lex retro non agit; czy też zasada specjalna - Ne ultra petita; argumenty, o których będzie mowa szerzej w dalszej części opracowania). ${ }^{9}$

W literaturze wyrażono pogląd, iż dyskurs prawniczy winien być prowadzony w pełnym zakresie jedynie dla przypadków trudnych, w innych zaś wypadkach metody wypracowane $\mathrm{w}$ tym dyskursie winny być wykorzystywane $\mathrm{w}$ ograniczonym stopniu. ${ }^{10}$ Przypadki trudne występują, gdy przewidzenie treści rozstrzygnięcia sądowego jest niemożliwie. Ma to miejsce w sytuacji, gdy sprawa nie jest prosta i standardowa, a więc może być zakończona dużą liczbą trafnych rozstrzygnięć. ${ }^{11}$

\section{Argumenty w dyskursie prawniczym}

Argumenty, obok zasad prawnych zaliczone przez J. Stelmacha i B. Brożka do topik prawniczych, są najczęściej pewnymi regułami nieformalnie rozumianej lo-

Zob. K. Kukuryk, Kilka uwag..., op. cit., s. 19.

Zob. J. Stelmach, B. Brożek, Metody..., op. cit., s. 204-211; reguły wyróżnione przez wskazanych wymienia S. Lewandowski, Retoryczne..., op. cit., s. 122-123; a także J. Oniszczuk, Filozofia..., op. cit., s. 774-777.

Zob. J. Stelmach, B. Brożek, Metody..., op. cit., s. 220.

Zob. M. Król, Koncepcje trudnych przypadków a prawomocność, Teoria prawa, Filozofia prawa, Współczesne prawo i prawoznawstwo, Toruń 1998, s. 97. 
giki, zróżnicowanymi w zakresie stopnia niezawodności, jak i możliwych ram ich zastosowania w dyskursie prawniczym. ${ }^{12} \mathrm{Z}$ argumentami spotykamy się, gdy dla uzasadnienia określonego poglądu - konkluzji argumentu, przedstawiane są jakieś zdania, nazywane przesłankami. Co do zasady, są one tworzone i przedkładane, aby dokonać zmiany przekonań określonej osoby lub grupy osób, prezentowane są zaś w ramach szerszej wypowiedzi - wypowiedzi argumentacyjnej..$^{13}$

Typowymi argumentami dla dyskursu prawniczego są według L. Lewandowskiego między innymi argumenty: a simili, a contrario, a fortiori. ${ }^{14}$

Argument a simili (,z podobieństwa”) polega na stosowaniu analogii w prawie, na założeniu, że w dwóch znacząco zbliżonych sytuacjach winno zapaść takie samo rozstrzygnięcie. ${ }^{15}$ Ten jeden $\mathrm{z}$ najczęściej stosowanych argumentów w dyskursie prawniczym może być użyty w owym dyskursie nie tylko w odniesieniu do konkretnej normy, ustawy (analogia legis), czy też porządku prawnego - systemu prawa krajowego (analogia iuris), ale również rozstrzygnięcia o charakterze precedensowym, zwyczaju, innej reguły, zasady prawnej. Można go zastosować pod warunkiem, że stwierdzi się podobieństwo między rozstrzyganym przypadkiem a przypadkiem, co do którego wcześniej zapadło rozstrzygnięcie. ${ }^{16}$

Argument a contrario jest przeciwieństwem wyżej wskazanego argumentu, polega na wnioskowaniu „z przeciwieństwa”, nie zaś „z podobieństwa”. Stanowi on dopełnienie argumentu $a$ simili. W sytuacjach, gdy dopuszczalne jest stosowane argumentu a simili nie można stosować argumentu a contrario i na odwrót. ${ }^{17}$ Argument a contrario przede wszystkim zastosowanie ma w prawie publicznym, z kolei a simili $\mathrm{w}$ prawie prywatnym. ${ }^{18} \mathrm{Jak}$ wskazuje się w literaturze cywilistycznej, wnioskowanie to należy stosować z ostrożnością, gdyż może ono prowadzić do błędnych wyników w sytuacji, gdy określony przepis nie określa hipotezy w sposób wyczerpujący. ${ }^{19}$

Argument a fortiori (łac. „od mocniejszego”) może przybrać postać argumentu a maiori ad minus (,,z większego na mniejsze") oraz argumentu a minori ad maius (,z mniejszego na większe”). ${ }^{20}$ Pierwszy z nich tworzony jest w oparciu o regułę pozytywną (,,jeżeli wolno więcej, to wolno również mniej”), drugi zaś oparty jest na regule negatywnej (,jeżeli nie wolno mniej, to nie wolno również więcej”). Wskazuje się, że reguła ta pod względem logicznym może być zawodna. ${ }^{21}$

Zob. J. Stelmach, B. Brożek, Metody..., op. cit., s. 212.

Zob. K. Szymanek, Sztuka argumentacji, Słownik terminologiczny, Warszawa 2001, s. 37.

Zob. S. Lewandowski, Retoryczne..., op. cit., s. 108-109.

Ibidem, s. 262.

Zob. J. Stelmach, B. Brożek, Metody..., op. cit., s. 212.

Zob. S. Lewandowski, Retoryczne..., op. cit., s. 269.

Zob. J. Jabłońska-Bonca, Prawnik a sztuka negocjacji i retoryki, Warszawa 2002, s. 253.

Zob. A. Wolter, I. Ignatowicz, K. Stefaniuk, Prawo cywilne - zarys części ogólnej, Warszawa 1996, s. 94.

Ibidem, s. 246.

Zob. J. Stelmach, B. Brożek, Metody..., op. cit., s. 213. 
Powoływanie się na zasadę słuszności jako argument w dyskursie prawniczym...

Najważniejszymi, zdaniem J. Stelmacha i B. Brożka, argumentami, które mogą być używane nie tylko w dyskursie prawniczym, ale również w innych dyskursach praktycznych, są, oprócz wyżej wymienionych argumentów, także: argument $a b$ exemplo (,,z przykładu"; pojawia się często w dyskursie prawniczym, oparty jest na założeniu podobieństwa między ,wzorcem” a przedmiotem, na który rozciągamy ten wzorzec), argument przez dowód nie wprost (negujemy nim prawdziwość, racjonalność, słuszność określonego twierdzenia przeciwnego twierdzeniu, które chcemy udowodnić, celem wykazania jego prawdziwości, słuszności, racjonalności), argument a loco communi (,„z miejsc wspólnych”; polega on na odwoływaniu się do topik ogólnych, a także np. fundamentalnych wartości, związanych z niewyspecjalizowym polem dyskursu prawniczego), argument a loco specifici (,,z miejsc specjalnych”), argument a cohaerentia (,,z niesprzeczności”; daje nam możliwość domagania się usunięcia z dyskursu prawniczego każdej tezy, będącej w sprzeczności z uznanymi tezami), argument a completudine (,,z zupełności”), argument a rerum natura (,,z natury rzeczy”), argument systematyczny, argument teologiczny, argument psychologiczny, argument socjologiczny, argument historyczny, argument ekonomiczny. ${ }^{22}$

W literaturze został również wyłoniony argument ze zmiany przepisów prawa, stanowiący narzędzie wykorzystywane w dyskursie interpretacyjnym. Polega on na tym, iż sądy, dokonawszy analizy zmiany przepisów, znajdują racje na rzecz określonego rozstrzygnięcia spornej kwestii. Wyróżnia się dwa warianty rzeczonego argumentu. Pierwszy występuje, gdy zmiana jest istotnym argumentem, przemawiającym na rzecz rozumienia starego przepisu, drugi zaś w sytuacji, kiedy zmiana wykorzystywana jest jako zaświadczenie o prawidłowym rozumieniu nowego przepisu. $^{23}$

Innym istotnym argumentem, często występującym w dyskursie prawniczym, jest argument z autorytetu. Polega on na tym, że dokonuje się uzasadnienia określonego poglądu poprzez powołanie się na fakt, iż podziela go autorytet osobowy lub autorytet zbiorowy ${ }^{24}$ (a więc np. na pogląd wyrażony w określonym orzeczeniu Sądu Najwyższego).

W przypadku dyskursu prawniczego, dążącego do rozstrzygnięcia konfliktu uprawnień, możemy mieć do czynienia z argumentacją, odwołującą się do zasad (która nie podporządkowuje uprawień zbiorowemu celowi, tylko przedstawia metodę mechanizmu wyważenia uprawień abstrakcyjnych; stanowi odpowiedź na pytanie o istnieniu uprawnienia), argumentacją ekonomiczną (polegającą na zbadaniu zbiorowej sumy użyteczności prawnej dwóch konkurencyjnych uprawnień abstrak-

\footnotetext{
22 Ibidem, s. 212-216.

23 Zob. A. Bielska-Brodziak, Z. Tobor, Zmiana w przepisach jako argument w dyskursie interpretacyjnym, PiP 2009, z. 9, s. 18 (szerzej s. 18-32). O argumencie ze zmiany przepisów prawa także T. Grzybowski, Wpływ zmian prawa na jego wykładnię, Warszawa 2013, s. 178-215. 
cyjnych) oraz argumentacją polityczną (dającą odpowiedź na pytanie, co jest najlepsze dla wspólnoty jako całości). ${ }^{25}$

Powyżej wymienione argumenty nie wyczerpują oczywiście katalogu argumentów możliwych do zastosowania $\mathrm{w}$ dyskursie prawniczym. $\mathrm{Z}$ argumentów typowo prawniczych można jeszcze wyróżnić argumenty a rubrica (,z systematyki”), czy ad absurdum (odwołujący się „do absurdu”), zaś z argumentów wykorzystywanych nie tylko przy argumentacji prawniczej np. argument ad consequentiam (,do następstw”), argument ad ignorantiam (,do niewiedzy”). ${ }^{26}$

\section{Powołanie się na zasadę słuszności jako argument w dyskursie prawniczym}

Zagadnienie powoływania zasady słuszności jako argumentu w dyskursie prawniczym należy rozpocząć od zaprezentowania pojęcia klauzuli generalnej. Jak zdefiniował Z. Radwański, „klauzula generalna to zwrot niedookreślony zawarty $\mathrm{w}$ przepisie prawnym oznaczający pewne oceny funkcjonujące $\mathrm{w}$ jakiejś grupie społecznej, do których odsyła ów przepis przez nakaz uwzględnienia ich przy ustalaniu stanu faktycznego podpadającego pod daną normę". ${ }^{27} \mathrm{~W}$ stosowaniu prawa, dzięki odesłaniom pozaprawnym, organ orzekający uzyskuje pewien luz decyzyjny. ${ }^{28}$ Funkcją klauzul generalnych jest stworzenie bowiem wartości elastyczności w procesie decyzyjnym albo też wzmocnienie tej wartości tam, gdzie występuje ona w związku z innymi źródłami wspomnianego luzu. ${ }^{29}$

Przepisem, w którym zawarte są klauzule generalne, czy też w szerokim ujęciu, będącym klauzulą generalną, jest art. 5 k.c. ${ }^{30}$ Stanowi on, iż nie można czynić ze swego prawa użytku, który by był sprzeczny ze społeczno-gospodarczym przeznaczeniem tego prawa lub z zasadami współżycia społecznego. Takie działanie lub zaniechanie uprawnionego nie jest uważane za wykonywanie prawa i nie korzysta $\mathrm{z}$ ochrony. Od zawartych w przepisie art. 5 k.c. dwóch kryteriów uzależniona jest ocena zachowania się podmiotu określonego prawa. Mianowicie, działanie lub zaniechanie podmiotów prawa cywilnego mieści się $\mathrm{w}$ granicach prawa cywilnego, dopiero gdy pozostaje z nim w zgodności. ${ }^{31}$ Wyjątkowy charakter normy wynikającej z art. 5 k.c. podkreślił Sąd Najwyższy w uzasadnieniu wyroku z dnia 9 grudnia 2009 roku, sygn. akt IV CSK 290/09 (niepubl., LEX nr 560607), stwierdzając, że przełamuje ona zasadę, iż wszystkie prawa podmiotowe korzystają z ochrony praw-

Zob. M. Pełka, Konflikt uprawień w teorii prawa Ronalda Dworkina, Warszawa 2012, s. 200-202.

Zob. S. Lewandowski, Retoryczne..., op. cit., s. 108-112.

Zob. Z. Radwański, Prawo cywilne - część ogólna, Warszawa 2005, s. 52.

Zob. S. Wronkowska, Z. Ziembiński, Zarys teorii prawa, Poznań 2001, s. 216.

Zob. L. Leszczyński, Stosowanie generalnych klauzul odsyłających, Zakamycze 2003, s. 182.

W tym zakresie przedstawia poglądy doktryny m.in. T. Justyński, Nadużycie prawa w polskim prawie cywilnym, Zakamycze 2001, s. 93-94.

Zob. T. Justyński, Nadużycie... op. cit., s. 93. 
Powoływanie się na zasadę słuszności jako argument w dyskursie prawniczym...

nej. Jak zaś wskazała M. Pyziak-Szafnicka, to właśnie dzięki konstrukcji nadużycia prawa podmiotowego urzeczywistnić mogą się nakazy społeczne i zasady etyczne, które choć nieczęsto występują w treści prawa pozytywnego, stanowią fundament całego porządku prawnego. ${ }^{32}$

Z dwóch zawartych w przepisie art. 5 k.c. klauzul, w obecnej sytuacji politycznej i gospodarczej, większe znaczenie mają zasady współżycia społecznego. ${ }^{33}$ W doktrynie podnosi się, iż zasady współżycia społecznego są regułami moralnymi, odnoszącymi się do stosunków międzyludzkich, ${ }^{34}$ odwołującymi się do uznawanych w kulturze wartości, idei słuszności w prawie oraz wolności ludzi. ${ }^{35}$ Utożsamia się je też z zasadami etycznego postępowania. ${ }^{36} \mathrm{~J}$. Justyński, popierając wyrażony w doktrynie pogląd, stwierdził, że ,zastosowanie klauzuli współżycia społecznego w konkretnych przypadkach w niczym nie odbiega od stosowania wcześniej znanych naszemu prawu cywilnemu klauzul słusznościowych". 37

Ramy stosowania art. 5 k.c. próbował wyznaczyć Trybunał Konstytucyjny w wyroku z dnia 17 października 2000 roku SK 5/99 (OTK Zb. Urz. 2000, nr 7, poz. 254) (w którym to wyroku orzekł, iż art. 5 k.c. jest zgodny z art. 2 i art. 45 ust. 1 Konstytucji Rzeczypospolitej Polskiej oraz nie jest niezgodny z art. 32 ust. 1 i art. 64 ust. 2 w zw. z art. 20 Konstytucji). TK uznał, iż obecność w art. 5 k.c. klauzul odsyłających powoduje elastyczność jego stosowania, lecz zakres tego uelastycznienia nie jest nieograniczony. Nie ma bowiem podstawy, aby stosować art. 5 k.c. samoistnie, czy też celem zastępowania innych norm. Nie może on stanowić narzędzia interpretowania prawa. Dopuszczalna jest jedynie subsumpcyjna rola tego przepisu. Sama zaś interpretacja art. 5 k.c. winna być ścisła i jednolita na tyle, aby przesłanki rozumienia tego przepisu miały obiektywny charakter. Z art. 5 k.c. należy korzystać rozważnie i z odpowiednią ostrożnością. ${ }^{38}$

Twierdzenia TK nie obeszły się jednak bez krytyki. Wątpliwości wzbudziła bowiem teza o obiektywizacji kryteriów nadużycia prawa. Jak wskazał L. Leszczyński, ,interpretacja klauzul generalnych zawsze zawiera elementy subiektywne, zależne od indywidualnych zapatrywań i priorytetów. Dotyczy to także sądu, który obok ustalania preferencji społecznych oraz przekonań środowiska sędziowskiego z pewnością będzie brał pod uwagę własne odczucia. Nawet wówczas, gdy stara się precyzyjnie ustalić preferencje społeczne (...) i jest uwikłany we własne oceny

\footnotetext{
32 Zob. M. Pyziak-Szafnicka, Komentarz do art. 5 Kodeksu cywilnego, (w:) Kodeks cywilny, Część ogólna, Komentarz, (red.) M. Pyziak-Szafnicka, LEX 2009.

33 Zob. S. Dmowski, aktualizacja R. Trzaskowski, Nadużycie prawa podmiotowego, (w:) Kodeks cywilny, Komentarz, T. I, (red.) J. Gudowski, Warszawa 2014, s. 52.

34 Zob. M. Pyziak-Szafnicka, Prawo podmiotowe, (w:) System Prawa Prywatnego, Tom I, (red.) M. Safjan, Warszawa 2012, s. 907.

35 Zob. S. Dmowski, aktualizacja R. Trzaskowski, Nadużycie..., op. cit., s. 50.

36 Zob. A. Zbiegień-Turzyńska, Nadużycie prawa, (w:) Kodeks cywilny, Komentarz, Tom I, (red.) K. Osajda, Warszawa 2013, s. 312;

37 Zob. T. Justyński, Nadużycie..., op. cit., s. 111.

38 Zob. L. Leszczyński, Stosowanie generalnych klauzul odsyłających, Kraków 2003, s. 416-447.
} 
(...) subiektywizm jest więc tu naturalny". ${ }^{39}$ Podobnie, po przedstawieniu poglądów przeciwko obiektywizacji kryteriów nadużycia prawa, stwierdziła M. Pyziak-Szafnicka: „postulat przewidywalności rozstrzygnięć zapadających z uwzględnieniem art. $5 \mathrm{kc}$. z założenia jest trudny do zrealizowania, skoro zawsze chodzi o sytuacje szczególne, w którym występują okoliczności nadzwyczajne, niepowtarzalne i dlatego nieprzewidziane przez ustawodawcę w treści przepisu". ${ }^{40}$

Trudno z powyższymi twierdzeniami polemizować. Dodać ponadto należy, iż możliwość zastosowania $\mathrm{w}$ określonym przypadku klauzul z art. 5 k.c. może często stanowić dla organu orzekającego wspomniany w pierwszym rozdziale „trudny przypadek". Decyzję bowiem o skorzystaniu z możliwości, jakie dają klauzule z tego przepisu, w szczególności zasady współżycia społecznego, będą poprzedzały rozważania, czy w konkretnym przypadku (często właśnie wyjątkowym), na ochronę zasługuje prawo podmiotowe jednej ze stron postępowania, czy też może z uwagi na jego nadużycie, prymat należy dać ideom słuszności, moralności. Werdykt zaś w takiej sytuacji będzie w większości przypadków trudny do przewidzenia, jego zaś trafność zawsze dyskusyjna.

Powoływanie się na zasadę słuszności nie zostało wymienione jako jeden $\mathrm{z}$ argumentów w dyskursie prawniczym przez J. Stelmacha i B. Brożka. Autorzy ci podali jednak, iż jednym z kryterium dyskursu prawniczego jest właśnie słuszność. ${ }^{41}$ Problematykę stosowania przepisów odsyłających do kryteriów, takich jak np. reguły słuszności, w zakresie argumentacyjnym, poruszył za to L. Leszczyński. ${ }^{42}$ Próbując zdefiniować pojęcie „stosowania klauzul”, stwierdził, iż w ujęciu szerszym (luźniejszym), mogłoby ono obejmować również wykorzystanie tychże norm odsyłających w uzasadnieniu decyzji. Podniósł, że ,przy założeniu, że uzasadnienie decyzji, będące immanentną częścią procesu decyzyjnego, jest przede wszystkim racjonalizowaniem procesu decyzyjnego i treści podjętej decyzji stosowania prawa oraz racjonalizowaniem stosowania zastosowania klauzuli oraz ustalenia jej treści (jej interpretacji), nawet potraktowanie klauzuli jako jedynie argumentu erystycznego oznaczać musi jej udział w całym procesie". ${ }^{43}$ Wskazał, iż oparcie decyzji na klauzuli odsyłającej może znaleźć i zwykle znajduje odzwierciedlenie w treści uzasadnienia decyzji finalnej. Przez co argumenty aksjologiczne zaczynają spełniać funkcję argumentów, które przekonują do trafności rozstrzygnięcia. Poprzez oparcie decyzji na normie odsyłającej, argumenty takie mogą mieć większe znaczenie, aniżeli argumenty jurydyczne. To bowiem argumenty aksjologiczne przede wszyst-

Zob. L. Leszczyński, Glosa do wyr. TK z dnia 17 października 2000 roku, PS 5/99, s. 70; L. Leszczyński, Stosowanie..., op. cit., s. 430 .

Zob. M. Pyziak-Szafnicka, Prawo podmiotowe..., op. cit., s. 883-884.

Zob. J. Stelmach, B. Brożek, Metody..., op. cit., s. 179-180.

Zob. L. Leszczyński, Stosowanie..., op. cit., s. 28.

Ibidem, s. 34-35. 
Powoływanie się na zasadę słuszności jako argument w dyskursie prawniczym...

kim prowadzą do wykazania racjonalności i trafności rozstrzygnięcia o określonej treści. ${ }^{44}$

Opierając się na powyższych twierdzeniach L. Leszczyńskiego, należy przyjąć, iż uzasadnianie powołania się na zasady współżycia społecznego przez sąd przy odmowie skorzystania, bądź ograniczeniu możliwości skorzystania przez określony podmiot $\mathrm{z}$ jego prawa podmiotowego, może pełnić również rolę argumentu w dyskursie prawniczym - argumentu poprzez odwołanie się do moralności, wartości etycznych. Niewątpliwie tego typu argumentacja słusznościowa jest pod względem retorycznym silna. Wymusza bowiem na mającym przywilej repliki adresacie konieczność ewentualnego podważenia ocen aksjologicznych organu orzekającego bądź też podniesienia kwestii braku możliwości powołania się na zasadę słuszności w określonej sytuacji prawnej.

\section{Argumenty w uzasadnieniach orzeczeń Sądu Najwyższego (dotyczących stosowania art. 5 k.c. jako podstawy obniżenia spłat lub dopłat z udziałów przy podziale majątku wspólnego)}

Orzeczenia, które zostaną przeanalizowane pod kątem użytych argumentów, będą dotyczyć kwestii, czy na podstawie przepisu art. 5 k.c. istnieje możliwość obniżenia spłaty lub dopłaty z udziałów przy podziale majątku wspólnego byłych małżonków. A tym samym, czy w oparciu o konstrukcję nadużycia prawa podmiotowego można pozbawić uprawnionego ekwiwalentu prawa własności w postaci stosownej kwoty tytułem wyrównania udziałów w dzielonym majątku.

Pierwszym orzeczeniem, w którym poruszono przedmiotową kwestię, było postanowienie z dnia 25 maja 1998 roku, sygn. akt I CKN 684/97 (niepubl., LEX nr 477333).

W sprawie o podział majątku wspólnego Sąd Rejonowy, przyznając wnioskodawczyni jedyny pozostający do podziału składnik, tj. spółdzielcze lokatorskie prawo do lokalu, zaniechał zasądzenia od niej spłaty na rzecz uczestnika postępowania, w oparciu o art. 5 k.c., co uzasadniał między innymi jej trudną sytuacją majątkową i rodzinną, niezdolnością do spłacenia byłego męża. Sąd Wojewódzki, uznając powyższe rozstrzygnięcie za niezgodne $\mathrm{z}$ art. 46 Kodeksu rodzinnego i opiekuńczego (Dz.U. 1964 Nr 9 poz. 59 ze zm.) oraz art. 1035 k.c. i 212 § 1 pkt 1 k.c., jednocześnie przyznając, iż wnioskodawczyni jest niezdolna do wyrównania udziału męża, zmienił orzeczenie sądu I instancji w ten sposób, że dokonał miarkowania spłaty, poprzez zmniejszenie wartości wyżej wskazanego składnika majątkowego.

Sąd Najwyższy, używając wnioskowania a maiori ad minus, stwierdził, że Sąd Wojewódzki prawidłowo uznał, że art. 212 § 1 k.c. (w zw. z art. 46 KRO oraz 1035 
k.c.) nie daje podstaw do zaniechania zasądzenia spłaty. Zauważył jednak, że również dokonane przez Sąd miarkowanie należnej spłaty jest także w świetle wskazanych przepisów niedopuszczalne.

Następnie wyraził pogląd, iż pomimo powyższego, można dokonać miarkowania spłaty zgodnie z art. 5 k.c., o ile istnieją przesłanki do ustalenia, że domaganie się przez uczestnika spłaty wkładu w pełnej wysokości stanowi nadużycie prawa. Twierdzenie to uzasadniał, przy użyciu argumentu z autorytetu, powołując się na uchwałę Sądu Najwyższego z dnia 30 listopada 1974 r. - III CZP 1/74, OSNCP z 1975 r., poz. 37 (określającą wytyczne wymiaru sprawiedliwości i praktyki sądowej w zakresie stosowania przepisów o podziale majątku wspólnego małżonków w wypadku, gdy w skład tego majątku wchodzi spółdzielcze prawo do lokalu; w której to uchwale dopuszczano możliwość miarkowania spłaty na podstawie art. 5 k.c.).

W oparciu o powyższą argumentację, Sąd Najwyższy uznał, że artykuł 212 k.c. nie stwarza sądowi orzekającemu w sprawie o podział majątku możliwości zaniechania zasądzenia spłaty ani obniżenia jej wysokości, wynikającej z wartości udziałów, a następnie dokonał modyfikacji orzeczenia Sądu Wojewódzkiego jedynie w zakresie, w jakim Sąd ten zmienił ustaloną wartość składnika majątkowego (nie zmieniając jednocześnie orzeczenia w zakresie zmniejszonej na skutek zmiany wartości składnika majątkowego spłaty).

Inny pogląd na przedmiotowy temat wyraził Sąd Najwyższy w uzasadnieniu postanowienia z dnia 6 stycznia 2000 roku, sygn. akt I CKN 320/98 (OSP 2001, nr 9, poz. C 136), zapadłego na tle następującego stanu faktycznego.

Sąd Rejonowy dokonał podziału majątku wspólnego byłych małżonków, przyznając kobiecie spółdzielcze lokatorskie prawo do lokalu mieszkalnego oraz ruchomości. Zasądzoną od niej na rzecz byłego męża spłatę obniżył w oparciu o art. 5 k.c. Powołał się na trudną sytuację majątkową i osobistą uczestniczki, pozostawienie jej bez środków do życia przez wnioskodawcę. Sąd Wojewódzki uznał to orzeczenie za trafne. Uczestniczka postępowania w kasacji, zarzucając między innymi naruszenie art. 5 k.c. wskazała, iż winna była zostać w całości zwolniona od spłaty.

Sąd Najwyższy, uzasadniając wyrok oddalający kasację, rozpoczął od zastosowania argumentu a contrario. Wskazał mianowicie, że skoro możliwość obniżenia spłaty daje art. $216 \S 2$ k.c. (odnoszący się do obniżenia spłaty przy zniesieniu współwłasności gospodarstwa rolnego), w innych wypadkach zniesienia współwłasności i działu (podziału) mas majątkowych, do których mają odpowiednie zastosowanie przepisy o zniesieniu współwłasności (art. 1035 k.c., art. 46 k.r.o.), a więc także w razie podziału majątku wspólnego między małżonkami, zdaje się być niedopuszczalne, w szczególności na podstawie art. 5 k.c., obniżenie spłaty należnej osobie uprawnionej do jej otrzymania.

Następnie Sąd Najwyższy, ponownie używając wnioskowania a contrario, wskazuje, że jeżeli nie dojdzie do pozbawienia małżonka części udziału (czy też całości udziału mu przysługującego) w majątku wspólnym na podstawie art. 43 
Powoływanie się na zasadę słuszności jako argument w dyskursie prawniczym...

$\S 1$ k.r.o., przy którego stosowaniu bierze się pod uwagę między innymi zasady współżycia społecznego, to podział tego majątku nie może doprowadzić do pozbawienia małżonka prawa własności, przysługującej mu w wyniku podziału części tego majątku, odpowiadającej wielkości jego udziału w tym majątku.

W dalszej kolejności Sąd Najwyższy wskazuje, iż zastosowanie art. 5 k.c. nie może stanowić podstawy obniżenia spłaty lub dopłaty należnej jednemu z małżonków w wyniku podziału majątku wspólnego, albowiem doszłoby w takiej sytuacji do pozbawienia tego małżonka substratu majątkowego, odpowiadającego jego prawu własności w majątku wspólnym (udziałowi w tym majątku), co godziłoby w prawo własności gwarantowane przez Konstytucję RP (art. 21 ust. 1, art. 64 ust. 2). Argument ten można zakwalifikować jako argument a loco communi. SN bowiem dla potwierdzenia swej tezy odwołał się do fundamentalnego prawa chronionego ustawą zasadniczą. Ponadto jest to argumentacja odwołująca się do zasad. Sąd Najwyższy dał bowiem do zrozumienia, że opartego na solidnych podstawach uprawnienia jednego z małżonków nie można naruszyć, nawet, gdy możliwość użycia prawa podmiotowego tej strony stałaby w kolizji z zasadami współżycia społecznego.

Wracając do omawianego orzeczenia - swą argumentację SN wieńczy, wskazując, iż wspomniany art. $216 \S 2$ k.c., jak słusznie zwrócono uwagę w piśmiennictwie (argument z autorytetu), pozostaje w sprzeczności z konstytucyjną zasady ochrony prawa własności. Zastosował tym samym ponownie argumenty wskazane w poprzednim akapicie, a także argument a cohaerentia (postulując pośrednio, aby wykluczyć z systemu prawnego przepis sprzeczny z fundamentalną zasadą).

Powyższe postanowienie spotkało się ze sporym zainteresowaniem glosatorów. ${ }^{45}$ Przy czym, co istotne dla analizy orzeczeń pod kątem zastosowanych argumentów, M. Niedośpiał i T. Justyński odnieśli się do zastosowania wnioskowania a contrario, dla przyjęcia, że w świetle art. $216 \S 2$ k.c. niedopuszczalne jest obniżenie spłat na podstawie art. 5 k.c. Pierwszy z nich wskazał, że hipoteza art. 216 k.c. nie wyklucza innych sytuacji obniżenia spłat. ${ }^{46}$ Drugi natomiast zadał pytanie, czy Sądowi Najwyższemu chodziło o zwykłe wnioskowanie a contrario, czy też o przekonanie, że skoro stworzono normę, która pozwala na obniżenie spłat w konkretnym przypadku, to brak dalszych tego typu norm świadczy o woli ustawodawcy o wyłączeniu takiej możliwości w innych przypadkach, a więc np. przy zastosowaniu art. 5 k.c. Nie rozstrzygając wątpliwości podniósł, że obie wskazane opcje nie pozwalają na osiągnięcie odpowiednich rezultatów. Stwierdził, że wnioskowanie a contrario jest zawodne, a przepis art. $216 \S 2$ k.c. nie daje podstaw, aby je stosować, gdyż jego treść nie wyklucza istnienia innych sytuacji, w których obniżenie spłat byłoby moż-

Zob. M. Niedośpiał, Glosa do postanowienia z 6 I 2000, I CKN 320/98, PiP 2001, nr 2, s. 110-112; T. Smyczyński, Postanowienie Sądu Najwyższego - Izba Cywilna z dnia 6 stycznia 2000 r., I CKN 320/98, Glosa, OSP 2001, nr 9, poz. C 136, s. 467-468; T. Justyński, Glosa do postanowienia z dnia 6 stycznia 2000 r. (I CKN 320/98), PS 2001 nr 10, s. 141-146; S. Dmowski, Przegląd orzecznictwa z zakresu kodeksu rodzinnego i opiekuńczego za lata 1998-2000, PS 2001, nr 9, s. 114-116.

Zob. M. Niedośpiał, Glosa..., op. cit., s. 111. 
liwie. Kolejne zaś rozumowanie jest wadliwe, albowiem nawet przy braku regulacji z art. 216 k.c., jego zdaniem, korekta wysokości spłaty na podstawie art. 5 k.c. nie byłaby dopuszczalna. Zaznaczył bowiem, iż stosowanie konstrukcji nadużycia prawa nie może w efekcie prowadzić do utraty jakiegokolwiek prawa podmiotowego. ${ }^{47}$ Jednocześnie T. Justyński zwrócił uwagę na argument SN o sprzeczności art. $216 \S 2$ k.c. z Konstytucją. Podkreślił, że był on słuszny, jednak wysiłek na jego stworzenie zbędny. Skład orzekający bowiem odwołał się do „nowych argumentów” dla „otwarcia drzwi już otwartych”. Powołał się przy tym glosator na ugruntowany pogląd $w$ doktrynie i judykaturze, iż zastosowanie przepisu art. 5 k.c. nie może prowadzić do pozbawienia prawa własności. ${ }^{48}$

Ostatnim analizowanym w niniejszej pracy orzeczeniem Sądu Najwyższego będzie postanowienie z dnia 22 stycznia 2009 roku, sygn. akt III CSK 251/08 (niepubl., LEX nr 507972), w którym to SN wyraził pogląd tożsamy z wyrażonym w orzeczeniu w sprawie o sygn. akt I CSK 684/97, a także polemizował ze stanowiskiem z orzeczenia wydanego w sprawie o sygn. akt I CKN 320/98.

Powyższe postanowienie zapadło na tle następującego stanu faktycznego.

Sąd Rejonowy dokonał podziału majątku wspólnego byłych małżonków poprzez przyznanie na rzecz kobiety odrębnej własność lokalu mieszkalnego o wartości 442.990 złotych. Uprzednim najemcą mieszkania był ojciec uczestniczki. Po jego śmierci córka wstąpiła w stosunek najmu po nim i wraz z małżonkiem wykupiła ona przedmiotowy lokal od Gminy na preferencyjnych zasadach, przy znacznej pomocy finansowej matki, przebywającej wówczas w celach zarobkowych za granicą. Uczestniczka mieszkała w tym lokalu z matką i niepełnosprawną córką. Mając na względzie te okoliczności Sąd uznał zasadnym w świetle zasad współżycia społecznego obniżenie spłaty poprzez ustalenie wartości lokalu na kwotę, jaką zainteresowani musieliby wyłożyć obecnie, tj. 120.620,93 złotych i połowę tej kwoty zasądził od uczestniczki na rzecz wnioskodawcy tytułem spłaty. Sąd Okręgowy uznał, powołując się na omawiane wcześniej postanowienie Sądu Najwyższego, syng. akt I CKN 320/98, iż niedopuszczalne jest obniżenie spłaty zgodnie z art. 5 k.c. W konsekwencji dokonał stosownej zmiany orzeczenia sądu I instancji.

Sąd Najwyższy, rozstrzygając zasadność kasacji uczestniczki postępowania stwierdził, iż wyłączenie w kategoryczny sposób dopuszczalności stosowania art. 5 k.c. w sprawach o podział majątku wspólnego nie znajduje racji bytu $z$ dwóch powodów. Wskazując na pierwszy, zastosował argument z autorytetu i powołał się na dominujący pogląd, przypomniany i podkreślony w uzasadnieniu postanowienia Sądu Najwyższego z dnia 24 stycznia 2007 r., sygn. akt III CZP 117/06 (OSNC 2007, $\mathrm{nr}$ 11, poz. 165). Mianowicie, poza nielicznymi wyjątkami nie ma podstaw do generalnego wyłączenia stosowania art. 5 k.c. w poszczególnych kategoriach spraw. 
Powoływanie się na zasadę słuszności jako argument w dyskursie prawniczym...

Wyjątkiem są sprawy, w których ze względu na ich specyfikę, art. 5 k.c. nie ma zastosowania, a więc sprawy o uzgodnienie treści księgi wieczystej z rzeczywistym stanem prawnym oraz o ustalenie nieważności czynności prawnej. Przytaczając drugi powód, Sąd Najwyższy ponownie zastosował argument z autorytetu, wytaczając tym razem cięższe armaty. Wskazał bowiem, iż koronny dowód powołany w postanowieniu w sprawie o sygn. I CKN 320/98, dotyczący sprzeczności stosowania art. 5 k.c. w omawianym przypadku z konstytucyjną ochroną własności, jest niezasadny, albowiem takiej sprzeczności co do zasady nie dopatrzył się Trybunał Konstytucyjny w wyroku z dnia 17 października 2000 r., SK 5/99. Następnie z uwagi, iż we wskazanym wyroku TK nie rozstrzygał zgodności art. 5 k.c. z art. 24 ust. 2 Konstytucji, który to przepis zgodnie ze zdaniem składu orzekającego w sprawie o sygn. akt I CKN 320/98, nie dawał uzasadnienia do obniżania spłat i dopłat na podstawie art. 5 k.c., Sąd Najwyższy podał, iż art. 21 ust. 2 Konstytucji odnosi się do wywłaszczenia na cele publiczne, dokonywane przez władzę publiczną. Zatem nie ma zastosowania do stosunków z prawa prywatnego. Wywiódł tym samym, iż w rezultacie nie ma podstaw, aby w sposób generalny wyłączyć możliwości zastosowania art. 5 k.c. w omawianym kontekście. Może zatem uznać, iż użył tym samym SN argument z dowodu nie wprost. Wykazał bowiem prawną nieprawidłowość twierdzenia składu orzekającego w sprawie I CKN 320/98, aby wykazać słuszność tezy przeciwnej.

Odnośnie rozstrzyganego przypadku, Sąd stwierdził, iż nie można przesądzić w obecnym stanie sprawy, czy zachodzą wyjątkowe okoliczności dopuszczające zastosowanie art. 5 k.c. Wobec potrzeby szczegółowego ustalenia co do sytuacji osobistej i majątkowej obojga byłych małżonków, uchylił zaskarżone postanowienie i przekazał sprawę do ponownego rozpoznania Sądowi Okręgowemu.

\section{Podsumowanie}

Analizowane w niniejszej pracy orzeczenia były względnie bogate w różnego rodzaju argumenty. Sąd Najwyższy stosował w nich, zarówno jedne z głównych wnioskowań w dyskursie prawniczym - a fortiori i a contrario, jak i inne argumenty: poprzez dowód nie wprost, a cohaerentia, a loco communi; czy też argumentację odwołującą się do zasad. Najbardziej powszechnym był jednak argument $\mathrm{z}$ autorytetu. Zastosowany został w pierwszym omawianym orzeczeniu oraz ostatnim (w drugim jego zastosowanie miało marginalne znaczenie). W obu stanowił główny argument za określonym rozstrzygnięciem. W obu powoływany autorytet był solidny - w pierwszym orzeczeniu była to uchwała SN zawierająca wytyczne, w drugim przede wszystkim istotny dla prawa cywilnego wyrok Trybunału Konstytucyjnego. Największa zaś gama różnych argumentów była domeną drugiego omawianego postanowienia, w którym został wyrażony inny pogląd niż w dwóch 
pozostałych. Być może wynikało to z faktu, iż niejako aspirowało ono do bycia ,precedensem", zmierzało do podważenia stosowania konstrukcji nadużycia prawa podmiotowego w omawianym przypadku i usankcjonowania określonej interpretacji art. 5 k.c., co skutkowało tym, że skład orzekający musiał sięgnąć do różnorodnych rodzajów argumentacji. Warto zauważyć, iż ze wskazanych trzech orzeczeń to właśnie postanowienie w sprawie o sygn. akt I CKN 320/98 było obiektem zainteresowania glosatorów.

W analizowanych orzeczeniach nie użyto argumentu poprzez zastosowanie art. 5 k.c., dla racjonalizacji określonego werdyktu. Składy orzekające rozważały bowiem, czy istnieje możliwość zastosowania art. 5 k.c. w określonej sytuacji prawnej. Nie oceniały, czy na gruncie danego stanu faktycznego doszło do nadużycia prawa podmiotowego. Argumentacja słusznościowa jest bowiem domeną głównie sądów powszechnych (co dało się zauważyć w stanach faktycznych analizowanych judykatów). To one bowiem, stojąc na pierwszej linii obrony wartości przed bezdusznym wykorzystywaniem nadanych przez prawo uprawnień, przybierając w konkretnym przypadku rolę „strażnika moralności”, aby obronić swoją decyzję, muszą ją racjonalizować poprzez użycie argumentów odwołujących się do aksjologii.

Kwestia stosowania art. 5 k.c. przy obniżaniu spłat i dopłat w postępowaniu o podział majątku wspólnego, w razie jej zaistnienia w toku sprawy, może być uznana za „trudny przypadek”. Sąd staje bowiem przed koniecznością oceny, czy zasady współżycia społecznego zostały na tyle naruszone, aby można było pozbawić uprawnionego ekwiwalentu prawa własności w postaci stosownej kwoty tytułem wyrównania udziałów w dzielonym majątku. Nawet przy założeniu, iż zastosowanie art. 5 k.c. w takiej sytuacji jest dopuszczalne, rozstrzygnięcie będzie trudne do przewidzenia. Kolizja bowiem prawa własności z regułami moralnymi jest kolizją poważną. Przy czym na rozstrzygnięcie duży wpływ będą miały nie tylko okoliczności rozpatrywanej sprawy, ale również pogląd na świat organu orzekającego. 
Powoływanie się na zasadę słuszności jako argument w dyskursie prawniczym...

\section{INVOKING THE PRINCIPLE OF EQUITY AS AN ARGUMENT IN LEGAL DISCOURSE ON THE EXAMPLE OF THE CASE LAW OF THE SUPREME COURT}

In the article the author presents the types of arguments in legal discourse, and discusses the issue of invoking the principle of equity as an argument in this kind of discourse. Furthermore, the case law of the Supreme Court is analysed, concerning the application of art. $5 \mathrm{CC}$ as the basis to reduce pay-offs or payments of shares on the division of assets in terms of the arguments used.

Keywords: principle of equity, argument, legal discourse, art. 5 CC, division of assets, general clause 